\title{
Leszek Butowski
}

Warsaw School of Tourism and Hospitality Management

\section{THE SCIENTIFIC IDENTITY OF TOURISM RESEARCH. POLISH VIEWS VERSUS THOSE OF FOREIGN ACADEMIA}

\begin{abstract}
The aim of this article is to present empirical results of a survey devoted to the issue of the scientific identity of Polish and international scholars of tourism. The survey has a firm theoretical background and the results are presented in the light of achievements of international literature. The article features: 1) a theoretical discussion and an overview of previous research and selected literary sources; 2) a presentation of the results of the author's empirical studies of the scientific identity carried out among Polish and international researchers of tourism; 3) more general conclusions related to the issues addressed in the paper.The empirical research project has the qualitative character (the non-representative survey on a purposeful sample) and was carried out in 2013 and 2014. The project covers two subsamples: international and Polish. The international subsample encompasses around 180 scholars of different scientific grades, age and experience in tourism research. The respondents represent leading public and private institutions (mostly universities as well as national and international tourism scientific associations and independent institutes) from almost 50 countries and all the continents. The Polish subsample includes 90 tourism scholars of various age, profile, experience and academic degree. They are representatives of the main national academic centres and scientific disciplines which deal with the issues related to tourism.The general results suggest that Polish scholars of tourism hold more conservative positions than their international colleagues as far as the recognition of the specific scientific identity of tourism research is concerned. At the same time it should be noted that some similarities in the Polish and international academia's views on the subject in question exist. Finally, it should also be stated that both Polish and international scholars dealing with tourism are internally divided as regards the methodological position of tourism research - es-
\end{abstract}

\footnotetext{
* E-mail address: 1.butowski@vistula.edu.pl.
} 
pecially its cognitive and formal status. The article develops certain ideas and findings presented in the previous works by the author focused mainly on the scientific identity of Polish scholars of tourism.

Keywords: scientific identity of tourism research, views of Polish and international scholars of tourism

\section{Introduction}

The aim of this paper is to present empirical results of a survey on the issue of the scientific identity of Polish and international scholars of tourism. The article features: 1) a theoretical discussion and an overview of the previous research and selected literary sources; 2) a presentation of the results of the author's empirical studies of the scientific identity carried out among Polish and international researchers of tourism; 3) conclusions related to the issues addressed in the paper - from a more general, methodological and theoretical perspective.

It seems that the problem of the academic identity of tourism researchers is closely related to the traditions of various particular disciplines which have been dealing with tourism issues for decades. The differences between the views of scholars from different countries, schools and disciplines with their paradigms testify to these factors playing an important role in the shaping of researchers' final opinions on the topic in question. The investigation of the said factors begins with a theoretical discussion in the first part of the paper. Having thus set the context, the results are subsequently discussed of the survey project conducted among scholars of tourism of various academic backgrounds from all around the world. In the conclusion, the author makes an attempt to sketch out the main factors, decisive as regards the present methodological situation of tourism research.

The article develops certain ideas and findings presented in the previous papers by the author ${ }^{1}$ and focused mainly on the scientific identity of Polish scholars of tourism.

L. Butowski, The phenomenology of tourism: in search of the essence of the phenomenon. Towards new paradigms for tourism research, in: Tourism Research in a Changing World, GITUR - Tourism Research Group of Polytechnic Institute of Leiria, eds. F. Dias, J. Kosmaczewska, E. Dziedzic, A. Mogliulo, 2014, pp. 250-265; L. Butowski, The ontological and epistemological foundations of tourism research. Scientific identity of Polish scholars of tourism, "Economic Problems of Tourism" 2014, No. 4 (28), pp. 23-38; L. Butowski, ed., Searching for the scientific identity of tourism research, Warsaw School of Tourism and Hospitality Management Warszawa 2014. 


\section{Literature review}

Tourism research has probably had the problem with its (and its researchers') identity from the very beginning, although it was not loudly expressed at that time. Some authors ${ }^{2}$ believe that a scientific analysis of tourism began in the first decades of the 20th century with Stradner's ${ }^{3}$, Glücksman's (who founded in Berlin, in the 1920s, the journal "Archiv für Fremdenverkehr") and especially Hunziker and Krapf's ${ }^{4}$ German-language works. In Poland, in 1936 the first academic tourism-related establishment - the 'Tourism Studium' at the Jagiellonian University in Cracow - was founded. ${ }^{5}$ Many authors ${ }^{6}$ agree that the contemporary study on the methodological and cognitive aspects of tourism research has grown gradually and has been present in the international literature for at least four decades. In the last years, reviews of different opinions on the methodological situation of tourism research have been published, among others, by Babu, Butowski, ${ }^{8}$ Ceriani-Sebregondi et al., ${ }^{9}$ Darbellay \& Stock, ${ }^{10}$ Echtner \& Jamal, ${ }^{11}$

2 Ceriani-Sebregondi G., Chapuis A., Gay J-C., Knafou R., Stock M., Violier P., Quelle serait l'objet d'une «science du tourisme»?, "Téoros" 2008, No. 27 (1), pp. 7-13.

3 J. Stradner, Der Fremdenverkehr, Leykam Graz 1905.

4 W. Hunziker, K. Krapf, Grundriss der allgemeinen Fremdenverkehrslehre, Polygraphischer Verlag, Zurich 1942.

5 J. Wyrzykowski, Achievements of geographical sciences in Poland in tourism research, in: Searching for the scientific identity of tourism research, ed. L. Butowski, Warsaw School of Tourism and Hospitality Management, Warszawa 2104, pp. 127-144.

6 D. Airey, Tourism Education Life Begins at 40, “Téoros" 2008, No. 27 (1), pp. 27-32; A. Borret, Discipline d'enseignement, sujet d'études, "Revue Espaces" 2005, No. 223, pp. 18-20; B. Kadri, La question du statut scientifique du tourisme : présentation, http://teoros.revues.org/345.

7 S.S. Babu, Tourism as Disciplines and Industry. Some comments on the progressing debates, in: Tourism Development Revisited. Concepts, Issues and Paradigms, eds. S.S. Babu, S. Mishra, B.B. Parida, SAGE 2008, pp. 33-53.

8 L. Butowski, Tourism - an academic discipline, "Turyzm" 2011, No. 21/1-2, pp. 17-24; L. Butowski, The phenomenology of tourism...; L. Butowski, The ontological...; L. Butowski ed., Searching for...

9 G. Ceriani-Sebregondi et al., Quelle serait...

10 F. Darbellay, M. Stock, Tourism as complex interdisciplinary research object, "Annals of Tourism Research" 2012, No. 39 (1), pp. 441-458.

${ }^{11}$ C.M. Echtner, T.B. Jamal, The Disciplinary Dilemma of Tourism Studies, "Annals of Tourism Research 1997, No. 24, pp. 868-883. 
Hillali, ${ }^{12}$ Taillon, ${ }^{13}$ Ratz; ${ }^{14}$ it should, however, be noted that they focus mainly on the aspects of disciplinarity vs. non-disciplinarity of tourism. Unfortunately, it seems that, despite many efforts, the general problem of the scientific identity of tourism studies is far from conclusion - both in the Anglo-Saxon ${ }^{15}$ and the Francophone literature. ${ }^{16}$ Three main positions held by the academics can be distinguished: in favour of tourism's own scientific identity (which could be probably best expressed by the recognition of tourism as a separate discipline), against it and an intermediate option.

The supporters of tourism's specific academic identity and, consequently, the disciplinarity of tourism studies such as Babu, ${ }^{17}$ Bosiacki $^{18}$ Goeldner $^{19}$ cited in Hall et al. ${ }^{20}$ (2004), Goeldner \& Ritchie, ${ }^{21}$ Jovicic ${ }^{22}$, Leiper, ${ }^{23}$ Page, ${ }^{24}$

12 M. Hillali, La science du tourisme dans le discours des acteurs internationaux; débat ou polémique?, "Téoros" 2008, No. 27 (1), pp. 42-50.

13 J. Taillon, Understanding tourism as an academic community, study, or discipline, "Journal of Tourism \& Hospitality" 2014, No. 3 (3), pp. 131-136.

14 T. Rátz, Crossdisciplinarity or tourismology? The scientific identity of tourism in Hungary, in: Searching for the scientific identity of tourism research, ed. L. Butowski, Warsaw School of Tourism and Hospitality Management, Warszawa 2014, pp. 35-57.

15 J.R.B. Ritchie, L.R. Sheenan, S. Timur, Tourism Sciences or Tourism Studies? Implications for the Design and Content of Tourism Programming "TÉOROS. Revue de Recherche en Tourisme" 2008, No. 27-1, pp. 33-41.

16 B. Kadri, La question...

17 S.S. Babu, Tourism as Disciplines...

18 S. Bosiacki (personal communication, 2013, 2014).

19 C.R. Goeldner, The evaluation of tourism as an industry and a discipline. Paper presented at the International Conference for Tourism Educators, University of Surrey Guildford 1988.

20 M. Hall, A. Williams, A. Lew, Tourism: Conceptualisations, Institutions and Issues, in: A Companion to Tourism, eds. A. Lew, M. Hall, A. Williams, Blackwell, Oxford 2004, pp. $3-21$

${ }^{21}$ C.R. Goeldner, J.R.B. Ritchie, Tourism: Principles, Practices, Philosophes, Hoboken (N.J.): John Wiley \& Sons 2006.

22 Z. Jovicic, A Plea for Tourismological Theory and Methodology, "Revue de Tourisme" 1988, No. 43, pp. 2-5.

23 N. Leiper, Towards a cohesive curriculum tourism: The case for a distinct discipline, “Annals of Tourism Research" 1981, No. 8 (1), pp. 69-84; N. Leiper, Tourism Systems: An Interdyscyplinary Study, "Occasion Papers" 1990, No. 2; N. Leiper, An Emerging Discipline, “Annals of Tourism Research" 2000, No. 27, pp. 805-809.

24 S.J. Page, Evaluating Research Performance in Tourism: The UK Experience, "Tourism Management" 2003, No. 24 (4), pp. 607-622. 
Ryan, ${ }^{25}$ Vicériat, Origet du Cluzeau \& Balfet ${ }^{26}$ raise different arguments pointing to the need for the recognition of tourism as a discipline. Some of them even proposed names for this new discipline, e.g. tourology $\left(\operatorname{Leiper}^{27}\right)$, tourismology $\left(\right.$ Jovicic $\left.^{28}\right)$, or turystologia $\left(\right.$ Chłopecki $\left.\mathrm{i}^{29}\right)$. Stafford ${ }^{30}$ proposes a new term téorologie, related to a field of study focused on tourism issues. He also identifies four paradigms (nominalist, economic-spatial, cultural, normative) which structure the research on tourism. Hoerner, ${ }^{31}$ and Hoerner \& Siccart ${ }^{32}$ appeal for the recognition of tourismologie as a multidisciplinary, human and applied science of a synthetic character, which focuses on voyage (in different aspects) as its research object. Leiper in his works argues for an academic identity and disciplinarity of tourism considering its social acceptance, which is manifested in the recognition of university curricula (in some countries, e.g. Australia, Canada, France, India, Poland, the UK, the USA - at least from the 1970s) at different levels of study, together with accompanying research programmes. As cited in Babu, ${ }^{33}$ quite similar views, though sometimes in different contexts, are presented by Ritchie et al., ${ }^{34}$ and Hall, Williams \& Lew $^{35}$

25 C. Ryan, Tourism a Mature Subject Discipline?, "Pacific Tourism Review" 1997, No. 1 (1), pp. 3-5; C. Ryan, Academia- industry tourism research links: states of confusion, "Pacific Tourism Review" 2001, No. 5 (3/4), pp. 83-96.

26 P. Vicériat, C. Origet du Cluzeau, M. Balfet, Ensemble pour la reconnaissance d'une science du tourisme, "Revue Espaces" 2005, No. 224, pp. 14-15.

27 N. Leiper, Towards a cohesive...

28 Z. Jovicic, A Plea for Tourismological...

29 J. Chłopecki, Turystologia jako dyscyplina naukowa, in: Turystyka $w$ badaniach naukowych, eds. R. Winiarski, W. Alejziak, AWF, WSIiZ, Kraków-Rzeszów 2005, pp. 263-274.

30 J. Stafford, Le paradigm culturaliste en téorologie: étude, analyse et critique, "Téoros" 1985, No. 7 (1), pp. 5-8.

31 J-M. Hoerner, Pour la reconnaissance d'une science touristique, "Revue Espaces" 2000, No. 173, pp. 18-20; J-M. Hoerner, Pour une novelle définition du tourisme, "Revue Espaces" 2002, No. 224, pp. 15-20; J-M. Hoerner, Contrubution à la science du tourisme, Retrieved October 23, 2014, from TEOROS web site: http://teoros.revues.org/355 Téoros, 27 (1), 2008.

32 J-M. Hoerner, C. Sicart, La science du tourisme, Balzac Editeur 2003.

33 S.S. Babu, Tourism as Disciplines...

34 J.R.B. Ritchie, L.R. Sheenan, S. Timur, Tourism Sciences...

35 M. Hall, A. Williams, A. Lew, Tourism: Conceptualisations, Institutions and Issues, in: A Companion to Tourism, eds. A. Lew, M. Hall, A. Williams, Blackwell, Oxford 2004, pp. 3-21. 
and even by Tribe ${ }^{36}$ who - being one of the most staunch opponents of a disciplined tourism - proposes bifurcation (in academic curricula) of the "body of tourism" into "Tourism Business Studies" and "Tourism Development Studies" $\left(\mathrm{Babu}^{37}\right)$.

Other authors, such as Barnett ${ }^{38}$ and Cuffy, Tribe \& Airey ${ }^{39}$ state that in countries where tourism education on a university level has been established for a long time, more abstract competences and critical thinking are expected. In the emerging markets, however, a more practical approach is dominant, as mentioned by Tooman, Müristaja \& Holleran ${ }^{40}$, Shariff ${ }^{41}$ and Rátz \& Kátay. ${ }^{42}$ Jovicic $^{43}$ calls for tourismology as a distinct discipline which could join and synthesise fragmented tourism research. He notes that "the observation of individual elements independently of the whole has resulted in a mistaken definition of tourism as an economic, geographic or sociological phenomenon" Stafford ${ }^{44}$ proposing his téorologie believes that such a field of inquiry will be able to integrate many elements from other disciplines at present scattered in time and space. Some other authors $\left(\mathrm{Cohen}^{45}\right.$,

36 J. Tribe, The Indiscipline of Tourism, "Annals of Tourism Research" 1997, No. 24, pp. 638-654; J. Tribe, The RAE-ification of tourism research in the UK, "International Journal of Tourism Research" 2003, No. 5, pp. 225-234.

37 S.S. Babu, Tourism as Disciplines..., p. 41.

38 R. Barnett, The idea of higher education, "Buckingham: The Society for Research into Higher Education”, Open University Press 1990; R. Barnett, Higher education, a critical business, "Buckingham: The Society for Research into Higher Education", Open University Press 1997.

39 V. Cuffy, J. Tribe, D. Airey, Lifelong Learning for Tourism, "Annals of Tourism Research" 2012, No. 39 (3), pp. 1402-1424.

40 H. Tooman, H. Müristaja, J.N. Holleran, Developing a Curriculum for the Needs of the Tourism Sector in a Transition Country, the Example of Pärnu College of the University of Tartu, Paper presented at the 25th EuroChrie Conference, Leeds, 25-27 October 2007.

41 N.M. Shariff, Reforming Hospitality Program of Higher Educational Institutions, "Anatolia - An International Journal of Tourism and Hospitality Research" 2011, No. 22 (1), pp. 125-128.

42 T. Rátz, Á. Kátay, Skills and Competencies in Tourism Employment-A Cultural Analysis of Expectations and Experiences, in: (Inter)cultural Aspects of Tourism Development, eds. T. Rátz, Cs. Sárdi, Kodolányi János University College, Székesfehérvár 2007, pp.89-100.

43 Z. Jovicic, A Plea for Tourismological..., p. 3.

44 J. Stafford, Connaissances en tourisme et reconnaissance sociale, "Téoros" 1992, No. 11 (1), pp. 44-46.

45 E. Cohen, Rethinking the sociology of tourism, “Annals of Tourism Research” JanuaryMarch 1979, pp. 110-111. 
Comic $^{46}$, Rogoziński ${ }^{47}$ ) agree with such opinions arguing that the study of tourism as the whole will suffer from a lack of in-depth analyses (analyses which should lead to the construction of stronger theoretical foundations) as long as the research is fragmented among various disciplines with their specific methods of investigation (Echtner \& Jamal ${ }^{48}$ ). They state that only through an integration of various branches of tourism research its theory will develop. In a similar context, Ritchie et al. ${ }^{49}$ propose their "core-foundation model" - used to distinguish between a hypothetical tourism theory (theories) and the theories of the foundation disciplines (e.g. sociological, geographical, economic). Trying to prove, with the use of formal analysis, that tourism has already been properly theorized, Mazurkiewicz ${ }^{50}$ goes even further than the above mentioned scholars. A large contribution to the development of theoretical foundations of tourism studies has been made by the MIT (Mobility, Itinerary, Tourism) team, which started its activity in 1993 (Ceriani-Sebregondi et al. ${ }^{51}$ ).

On the other hand, there are many opponents of tourism's own academic identity and disciplinarity who raise primarily methodological arguments against tourism studies with their specific academic identity. The numerous scholars such as Bowedes, ${ }^{52}$ Borret, ${ }^{53}$ Gołembski, ${ }^{54}$ Pearce,, 55 Tribe ${ }^{56}$ state that tourism does not have a commonly accepted definition and its own unique theories;

46 D. Comic, Tourism as a Subject of Philosophical Reflection, "Revue de Tourisme" 1989, No. 44 , pp. $6-13$.

47 K. Rogoziński, Tourism as a Subject of Research and Intergration of of Sciences, "Problemy Turystyki” 1985, No. 4, pp. 7-19.

48 C.M. Echtner, T.B. Jamal, The Disciplinary...

49 J.R.B. Ritchie, L.R. Sheenan, S. Timur, Tourism Sciences...

50 L. Mazurkiewicz, Czy istnieje teoria turystyki, „Problemy Turystyki” 2005, No. 3/4, pp. 155-167; L. Mazurkiewicz, Wybrane teorie oraz metody badawcze turystyki, Studia i Monografie AWF, Warszawa 2012.

51 G. Ceriani-Sebregondi, et al., Quelle serait...

52 T. Bowedes, Development of advanced tourism studies in Holland, "Annals of Tourism Resarch" 1982, No. 9, pp. 35-51.

53 A. Borret, Discipline...

54 G. Gołembski, personal communication, 2013.

55 P.L. Pearce, Defining Tourism Study as a Specialism: A Justification and Implications, “Téoros International 1" 1993, pp. 25-32.

56 J. Tribe, The Indiscipline... 
its weakest point from the ontological and epistemological perspectives. Even Goeldner \& Ritchie ${ }^{57}$ seeing the tourism's academic identity mainly within a set of management sciences admit that tourism lacks a unique definition. Witt, Broke $\&$ Buckley ${ }^{58}$ add that tourism research "will remain rather dynamic, variegated and at times internally conflictual." Franklin \& Crang $^{59}$ analysing the nature of tourism knowledge creation and the research community state that scholars are often under the dominance of politics and industry-sponsored research. Lynch $\&$ Brown $^{60}$ cited in $\mathrm{Babu}^{61}$ add an opinion that the "government and business persons believe that theoretical ideas are just 'excess baggage' of little value to practical realities of tourism management." Athiyaman ${ }^{62}$ criticises many a tourism researcher (especially the ones conducting tourism demand studies) for not contributing to the development of theoretical knowledge. Meethan ${ }^{63}$ assesses critically the content of journals, books and conferences which "remain untheorised, eclectic and disparate." A similar view is presented by Weiler, ${ }^{64}$ who does not agree with Jafari's ${ }^{65}$ observation that tourism research is no longer atheoretical. Baretje cited in Knafou ${ }^{66}$ states categorically that tourism is not and will never be a science, but a form of people's activity. In order to support

57 C.R. Goeldner, J.R.B. Ritchie, Tourism...

58 S. Witt, M. Broke, P. Buckley, The management of International Tourism, Unwin Hyman, London 1991.

59 A. Franklin, M. Crang, The Trouble with Tourism and Travel Industry, "Tourist Studies" 2001, No. 1 (1), Vol. 22.

${ }^{60}$ P. Lynch, R. Brown, Utility of Large-scale Leisure Research Agendas, "Managing Leisure" 1999, No. 7(4), pp. 63-77.

${ }^{61}$ S.S. Babu, Tourism as Disciplines..., p. 37.

62 A. Athiyaman, Knowledge development in tourism: Tourism demand research, "Tourism Management" 1997, No. 18 (4), pp. 221-228.

${ }^{63}$ K. Meethan, Tourism in Global Society: Place, Culture and Consumption, 2, Palgrave, New York 2001.

${ }^{64}$ B. Weiler, Tourism Research and Theories: A Review, in: Tourism and Hospitality Industry in the 21st Century, eds. A. Lockhood, S. Medlik, Butterworth-Heinemann, London 2003, pp. 82-93.

65 J. Jafari, Research and scholarship: The basis of toursm education, "Journal of Tourism Studies" 1990, No. 1, pp. 33-41.

66 R. Knafou, La recherche... 
the opinions which refuse to recognise tourism as a discipline, Tribe ${ }^{67}$ refers to Kuhn's ${ }^{68}$ classical works concerning the scientific paradigm and calls upon the notion of "normal science" - introduced by Kuhn - to describe the mature state of scientific disciplines. He states that tourism studies cannot be recognised as Kuhnian normal science and that tourism is at most at the pre-paradigm stage. Moreover, on the basis of Kuhn's model Echtner \& Jamal ${ }^{69}$ add that tourism studies will probably remain in the pre-paradigm phase due to the incommensurability of different disciplinary paradigms which have dealt with them.

Apart from the above mentioned arguments against tourism's own academic identity and disciplinarity there is another one raised up by Tribe ${ }^{70}$ in his well-known work concerning the truth about tourism. The author states that "disciplines may perform a selector role determining what is included and excluded in both the framing of research and its execution." In this context, Tribe, on the basis of Aronowitz \& Giroux's ${ }^{71}$ works, refers to the discipline's "tyrannical role" limiting research on tourism rather than supporting it. To illustrate his point, Tribe mentions Rojek \& Urry's ${ }^{72}$ and Franklin \& Crang's ${ }^{73}$ works, in which the authors identify the tyrannical role of economics in tourism research. It seems, however, that this opinion can be also reinterpreted in the context of tourism studies. An attempt to present such an interpretation is made in the conclusion to this paper.

Between these two opposite positions, a set of intermediate views, not so strong in their support or criticism of the tourism's scientific identity, can be distinguished. Some scholars, such as Ateljevic, Pritchard \& Morgan ${ }^{74} \mathrm{Babu},{ }^{75}$

67 J. Tribe, The truth about tourism, "Annals of Tourism Research" 2006, No. 33 (2), pp. 360-381.

68 T.S. Kuhn, The Structure of Scientific Revolutions, 3rd ed., University of Chicago 1996.

${ }^{69}$ C.M. Echtner, T.B. Jamal, The Disciplinary...

70 J. Tribe, The truth..., p. 366.

71 S. Aronowitz, H. Giroux, Postmodern education: politics, culture and social criticism, University of Minnesota Press, Minneapolis 1991.

72 C. Rojek, J. Urry, Touring cultures, Routledge, London 1997.

73 A. Franklin, M. Crang, The Trouble with Tourism and Travel Industry, "Tourist Studies" 2001, No. 1 (1), Vol. 22.

74 I. Ateljevic, A. Pritchard, N. Morgan, The critical turn in tourism studies: innovative research methodologies, Elsevier, Amsterdam, Netherlands 2007.

75 S.S. Babu, Tourism as Disciplines... 
Cazes, ${ }^{76}$ Dann, Nash \& Pearce, ${ }^{77}$ Jafari $^{78}$ and $\mathrm{Knafou}^{79}$ agree that tourism can be unquestionably treated as a field of study and they are ready to accept the statement that tourism studies are in the process of "gaining" maturity. Such an opinion at least partially corresponds to the previously mentioned Kuhn's paradigm model of science with its pre-paradigm phase where a future discipline (the studies of tourism) relies on various paradigms developed within other disciplines (Szubert-Zarzeczny ${ }^{80}$ ). Echtner \& Jamal ${ }^{81}$ remaining quite sceptical to the possibility of using Kuhn's paradigmatic model as the theoretical grounds for the separation of tourism studies admit that one cannot exclude the possibility of Kuhnian scientific revolution "in which a group of researchers breaks away from disciplinary boundaries and works to establish a distinct disciplinary matrix for tourism" taking place.

In this context, it is not only the question whether or not tourism studies can achieve their own, mature academic identity and be recognised as an independent discipline, but also - when. It seems that one of the most prominent proponents of such a position is Jafari ${ }^{82}$ who, identifying four development platforms of tourism studies, points to the knowledge-based platform being chronologically the latest and thus, the most actual. The same author referring to tourism claims: "Its scientific journey is clearly in progress, aiming at new frontiers, heading to new horizons" (cited in Babu ${ }^{83}$ ). Quite an optimistic perspective is also presented by Echtner \& Jamal ${ }^{84}$ when they suggest using (in opposition to Kuhn's paradigm

76 G. Cazes, À propos de tourismologie. La science par autoproclamation, "Revue Espaces' 2001, No. 187, pp. 46-53.

77 G. Dann, D. Nash, P. Pearce, Methodology in Tourism Research, "Annals of Tourism Research” 1988, No. 18, pp. 155-169.

78 J. Jafari, Research...

79 R. Knafou, La recherche en tourisme s'organise, „Revue Espaces” 2005, No. 225, pp. 11-14.

${ }^{80}$ U. Szubert-Zarzeczny, Kilka uwag o potrzebie autonomizacji ,nauki o turystyce”, Zeszyty Naukowe AWF w Krakowie No. 81, Kraków 2001, pp. 75-79.

81 C.M. Echtner, T.B. Jamal, The Disciplinary..., p. 876.

82 J. Jafari, Research...; J. Jafari, The Scientification of Tourism, in: Hosts and Guests Revisited: Tourism Issues in the 21st Century, eds. V.L. Smith, M.A. Brent, Cognizant Communication Corporation, New York 2001, pp. 28-41.

83 S.S. Babu, Tourism as Disciplines..., p. 39.

${ }^{84}$ C.M. Echtner, T.B. Jamal, The Disciplinary..., p. 878. 
model) Bernstein's ${ }^{85}$ approach concerning the methodological interrelations between natural (Naturwissenschaften) and social (Geisteswissenschaften) sciences.

So far the discussion has not mentioned another group of commonly-shared opinions, namely, those pointing to the future of tourism studies as a domain of inter- or cross-disciplinary approaches. Quite many scholars, such as Gołembski (personal communication, 2013), Liszewski, ${ }^{86}$ Pearce \& Butler, ${ }^{87}$ Tribe ${ }^{88}$ Witt et al. ${ }^{89}$ support such views arguing that they are consistent with the post-modern call for hybridisation/post disciplinarity; a point which answers the need for creativity and innovation. Other proponents of this option postulate "more pragmatic institutional perspectives on tourism's disciplinarity with scholarly potential and possibilities offered by post-disciplinarity" $\left(\mathrm{Babu}^{90}\right)$. Kadri ${ }^{91}$ believes that interdisciplinarity and cross-disciplinarity would allow tourism research to reduce its methodological handicap in relation to traditional disciplines. Dewailly ${ }^{92}$ remaining quite sceptical towards tourismologie, argues for transdisciplinarity in tourism research and proposes a "federative" paradigm able to encompass different anthropological, geographical and historical aspects as foundations for this new science. Moreover, for certain researchers even inter- and multidisciplinary approaches are already unsatisfactory. Coles, Hall \& Duvall ${ }^{93}$ claim that if studies of tourism are to reflect contemporary conditions, "they should move away from traditional approaches to more flexible forms of knowledge production." The same authors ${ }^{94}$ argue for a "hybrid approach" in tourism stud-

85 R. Bernstein, Beyond Objectivism and Relativism: Science, Hermeneutics and Praxis, University of Pennsylvania, Philadelphia 1991.

86 S. Liszewski, Nauka czy nauki o turystyce, ,Turyzm” 2010, No. 20 (2), pp. 37-45.

87 P.L. Pearce, R. Butler (eds.), Tourism Research: Critiques and Challenges, Routledge, London 1993.

88 J. Tribe, The truth...

89 S. Witt, M. Broke, P. Buckley, The management...

90 S.S. Babu, Tourism as Disciplines..., p. 36.

91 B. Kadri, La question...

92 J-M. Devailly, Géographie du tourisme. Pérégrinité ou chaos?, L'Harmattan, Paris 2006; J.-M. Dewailly, Complexité touristique et approche transdisciplinaire du tourisme, "Téoros" 2008, No. 27 (1), pp. 22-26.

93 T. Coles, M. Hall, D. Duvall, Mobilising tourism: A Post Disciplinary Critique, "Tourism Recreation Research" 2005, No. 31, 30 (2), pp. 31-42.

94 Ibidem, p. 39. 
ies. Nevertheless, it seems that, despite their appealing character, inter-, trans-, multi- and cross-disciplinary as well as hybrid approaches in tourism studies also have weak points, this to be discussed in the conclusion of the article.

The discussion in this section was only indicative and not meant to describe the issue comprehensively. On the other hand, it seems that during the last few years, the exchange of views on this topic has diminished; it has often been limited to reviewing works while omitting the presentation of their authors' positions. It probably suggests that the opponents and supporters of tourism's academic identity stay in their trenches and neither side is ready to compromise. Taking into account these circumstances and the apparent impossibility of achieving a consensus, a new approach is proposed in order to solve the problem in question. It offers a new insight based on a survey conducted among tourism scholars from all around the world.

\section{In search of the scientific identity of tourism research}

When we speak of the scientific identity (both in the ontological and in the epistemological context) of the studies of tourism, we should be looking for answers to the following research questions: 1) what should constitute the research object of the studies of tourism (ontological perspective); 2) in what wider context and aspect is this research object located; 3 ) in what way is research conducted and what do we want to learn (epistemological perspective); 4) with which scientific tradition do we identify ourselves; 5) within what wider paradigms do we conduct our research; and, 6) the output of which scientific discipline enriches the results of our research? The answers to at least some of these questions have been sought in the literature overview and in the empirical study and they will be presented in conclusion to this paper.

\section{Research method}

In order to analyse the problem of the scientific identity of tourism research, a three-stage research framework has been adopted, commencing with a directed literature review, investigating different positions on the subject followed by a qualitative survey of a purposeful sample of tourism academics and concluding with a further analysis of the literature, this time confronting empirical findings with identified scholars stances. 
Table 1

International respondents by continents and countries

\begin{tabular}{|c|c|c|c|}
\hline Continent & $\begin{array}{c}\text { Number } \\
\text { of respondents }\end{array}$ & Countries/ regions & $\begin{array}{c}\text { Number } \\
\text { of respondents }\end{array}$ \\
\hline Africa & 5 & RSA & 4 \\
\hline Asia & 12 & China, India \& Japan & 6 \\
\hline Australia \& Oceania & 7 & Australia \& New Zealand & 7 \\
\hline \multirow{7}{*}{ Europe } & \multirow{7}{*}{126} & $\begin{array}{l}\text { Austria, Germany } \\
\text { \& Switzerland }\end{array}$ & 20 \\
\hline & & Belgium \& Netherlands & 8 \\
\hline & & $\begin{array}{l}\text { Central \& Eastern Europe } \\
\text { (without Poland) }\end{array}$ & 17 \\
\hline & & France & 13 \\
\hline & & Scandinavia & 24 \\
\hline & & Southern Europe & 31 \\
\hline & & UK & 13 \\
\hline $\begin{array}{l}\text { North \& South } \\
\text { America }\end{array}$ & 23 & USA \& Canada & 19 \\
\hline $\begin{array}{l}\text { Data non-available } \\
\text { Poland }\end{array}$ & $\begin{array}{c}8 \\
89\end{array}$ & Other countries & 19 \\
\hline
\end{tabular}

Source: personal findings.

The sample includes respondents representing different disciplines, such as: geography, economics and business studies, management and marketing, regional studies, recreation, sport and leisure studies, sociology and anthropology, other social sciences and humanities. When constructing the sample, the principles similar to those adopted by Tribe ${ }^{95}$ and McKercher \& Prideaux ${ }^{96}$ were applied, although the present sample is bigger. The whole sample consists of two subsamples: international academics and Polish scholars of tourism. The "international" subsample includes about 180 scholars of different scientific grades (master's degree holders: $24 \%$, Ph.D. holders: $39 \%$, associate professors: $17 \%$ and full professors: $20 \%$ ), age and experience in tourism research. All of them have been asked to state whether they deal with tourism as the main ( $73 \%$ of respondents) or side $(27 \%)$ area of their academic interests. The international respondents

95 J. Tribe, Tribes, territories and networks in the tourism community, "Annals of Tourism Research" 2010, No. 37 (1), pp. 7-33.

96 B. McKercher, B. Prideaux, Academic myths of tourism, "Annals of Tourism Research" 2014, No. 46, pp. 16-28. 
represent the leading public and private institutions (mostly universities as well as national and international tourism scientific associations and independent institutes) from almost 50 countries and all the continents - Table 1 . (Africa: 3\% of respondents, Asia: 6\%, Australia \& Oceania: 4\%, Europe: 73\%, Americas: 14\%). The "international" questionnaires were distributed from April to November 2014 via e-mail.

The Polish subsample consists of 89 tourism scholars of various age, profile, experience and academic degree. They are representatives of the main national academic centres and scientific disciplines dealing with tourism-related issues (Table 2). $86 \%$ of the Polish respondents have stated that they deal with tourism as the main area of their scientific interests, while the remaining $14 \%$ treat tourism as a side field. Polish scholars were surveyed between June and December 2013.

Table 2

Structure of Polish subsample by academic specialisations, academic degree, and age (in \%)

\begin{tabular}{|l|c|c|c|c|}
\hline $\begin{array}{c}\text { Respondents } \\
\text { by academic specialisations }\end{array}$ & Economics & $\begin{array}{c}\text { Geographic } \\
\text { sciences }\end{array}$ & $\begin{array}{c}\text { Physical Culture } \\
\text { \& Sport }\end{array}$ & $\begin{array}{c}\text { Other } \\
\text { disciplines }\end{array}$ \\
\hline Part of the sample & 34 & 28 & 20 & 18 \\
\hline Respondents by academic degree & MA & Ph.D. & $\begin{array}{c}\text { Associate } \\
\text { Professor }\end{array}$ & Full Professor \\
\hline Part of the sample & 12 & 54 & 25 & 9 \\
\hline \multicolumn{1}{|c|}{ Respondents by age } & \multicolumn{2}{|c|}{11} & ages 36-50 & ages $>50$ \\
\hline Part of the sample & \multicolumn{2}{|c|}{28} & 61 \\
\hline
\end{tabular}

Source: personal findings.

The main body of the questionnaire consists of a series of structured questions concerning the academic identity of researchers and their methodological position towards tourism studies. The survey has been intended to answer the questions concerning: 1) the settlement of the studies of tourism within various scientific paradigms; 2) relationships of tourism scholars with various scientific traditions (scientific fields and disciplines); and, 3) the status and the methodological maturity of the studies of tourism. The concluding question reads: should the studies of tourism gain the status of an autonomous academic discipline? Additionally, respondents have been asked to provide short comments justifying their opinions. 


\section{Analysis - Polish sample}

The results of the survey allow certain observations as regards the scientific identity of tourism scholars.

1. Scientific paradigms in the studies of tourism:

a) the majority of respondents $(63 \%)$ claim that they conduct their research projects within the paradigms of traditional scientific disciplines; $24 \%$ of the respondents, however, state that they use specific paradigms of the studies of tourism - Figure 1, (13\% has not expressed an opinion on this matter);

b) it seems, also, that the bigger the theoretical output of a given discipline, the bigger the scholars' attachment to its paradigms (Economics $-86 \%$, Geography $-63 \%$, Physical Culture \& Sport - 35\%) - Table 3;

Table 3

Scientific paradigms in the studies of tourism by disciplines according to Polish respondents (in \%)

\begin{tabular}{|l|c|c|c|}
\hline \multicolumn{1}{|c|}{ Disciplines } & $\begin{array}{c}\text { Traditional } \\
\text { Paradigms }\end{array}$ & $\begin{array}{c}\text { Specific tourism } \\
\text { studies paradigms }\end{array}$ & Uncertain \\
\hline Economics & 86 & 11 & 3 \\
\hline Geography & 63 & 29 & 8 \\
\hline Physical Culture \& Sports & 35 & 41 & 24 \\
\hline Other disciplines & 50 & 21 & 29 \\
\hline
\end{tabular}

Source: personal findings.

c) the group of Full Professors (37\%) and Ph.D. holders (28\%) is relatively the most eager to recognise a new paradigm of the studies of tourism; the majority of the representatives of associate professors (68\%) claim that their research projects on tourism are conducted within paradigms of the traditional disciplines, the representatives of master's degree declare the highest number (27\%) of the "uncertain" responses (Table 4). 
Table 4

Scientific paradigms in the studies of tourism

by scientific degrees among Polish respondents (in \%)

\begin{tabular}{|l|c|c|c|}
\hline \multicolumn{1}{|c|}{ Scientific degree } & $\begin{array}{c}\text { Traditional } \\
\text { Paradigms }\end{array}$ & $\begin{array}{c}\text { Specific tourism } \\
\text { studies paradigms }\end{array}$ & Uncertain \\
\hline Master's & 64 & 9 & 27 \\
\hline Ph.D. & 61 & 28 & 11 \\
\hline Associate Professor & 68 & 18 & 14 \\
\hline Full Professor & 63 & 37 & 0 \\
\hline
\end{tabular}

Source: personal findings.

2. Tourism scholars and their relationships with various scientific traditions:

a) a slight (relatively) majority of the respondents claim that, when doing research on tourism, they feel they represent their mother disciplines (50\%), but $41 \%$ of the respondents state that they represent the Studies of Tourism understood as a new discipline (Figure 2), 9\% stated that they were "uncertain";

b) it seems that the scholars who originate from the disciplines dealing with tourism research for a longer period of time (i.a. Economics, Geography, Physical Culture \& Sports) are relatively more eager to call themselves representatives of the Studies of Tourism than scholars from other disciplines (Table 5);

Table 5

Polish researchers of tourism as representatives of traditional disciplines or the Studies of Tourism by represented discipline (in \%)

\begin{tabular}{|l|c|c|c|}
\hline \multicolumn{1}{|c|}{ Scientific disciplines } & Traditional disciplines & Studies of Tourism & Uncertain \\
\hline Economics & 52 & 48 & 0 \\
\hline Geography & 42 & 42 & 16 \\
\hline Physical Culture \& Sport & 47 & 47 & 6 \\
\hline Other disciplines & 62 & 19 & 19 \\
\hline
\end{tabular}

Source: personal findings.

c) it also seems that there is a certain correlation between the academic degree and the eagerness to call oneself a representative of the Studies of Tourism; the higher the academic degree of a person (Full Professors, associate professors), the more eager the person to call himself or herself a representative of the Studies of Tourism (Table 6). 
Table 6

Polish researchers of tourism as representatives of traditional disciplines or the Studies of Tourism by scientific degrees (in \%)

\begin{tabular}{|l|c|c|c|}
\hline Scientific degree & $\begin{array}{c}\text { Traditional } \\
\text { disciplines }\end{array}$ & $\begin{array}{c}\text { Studies } \\
\text { of Tourism }\end{array}$ & Uncertain \\
\hline Master's & 46 & 36 & 18 \\
\hline Ph.D. & 55 & 35 & 10 \\
\hline $\begin{array}{l}\text { Associate } \\
\text { Professor }\end{array}$ & 46 & 50 & 4 \\
\hline Full Professor & 38 & 62 & 0 \\
\hline
\end{tabular}

Source: personal findings.

3. The status of the Studies of Tourism as an autonomous scientific discipline (the term "Studies of Tourism" is used in this article in the broad sense, i.e. encompassing both the theoretical and the applied research on tourism (cf. Ritchie, Sheehan and Timur ${ }^{97}$ ).

a) quite an apparent majority (49\%) of the respondents state that the Studies of Tourism deserved the status of an autonomous scientific discipline; $32 \%$ of the respondents hold the opposing view, the remaining $19 \%$ have an unclear opinion on this matter;

b) $37 \%$ of the opponents of the autonomy of the Studies of Tourism held a Full Professor's degree (but it is worth mentioning that at the same time half of them declared 'yes' for tourism as an autonomous discipline), the proponents were mostly representatives of the remaining degrees (Table 7);

Table 7

Studies of Tourism as an autonomous discipline by scientific degrees according to Polish scholars (in \%)

\begin{tabular}{|l|c|c|c|}
\hline \multicolumn{1}{|c|}{ Scientific degree } & Yes & No & Uncertain \\
\hline Master's & 55 & 27 & 18 \\
\hline Ph.D. & 49 & 35 & 16 \\
\hline Associate Professor & 50 & 27 & 23 \\
\hline Full Professor & 37 & 37 & 26 \\
\hline
\end{tabular}

Source: personal findings.

97 J.R.B Ritchie, L.R. Sheehan, S. Timur, Tourism Sciences or Tourism Studies? Implications for the Design and Content of Tourism Programming, "Téoros. Revue de Recherche en Tourisme" 2008, No. 27-1, pp. 33-41. 
c) the majority of the scholars who had shorter experience with research on tourism were in favour of the separation of the Studies of Tourism as an autonomous discipline; the scholars with longer experience were equally divided between the two options (Table 8);

Table 8

Studies of Tourism as an autonomous discipline

by years of experience in researching tourism in Polish subsample (in \%)

\begin{tabular}{|l|c|c|c|}
\hline $\begin{array}{c}\text { Experience } \\
\text { in tourism research }\end{array}$ & Yes & No & Uncertain \\
\hline$\leq 10$ years & 64 & 14 & 22 \\
\hline$>10$ years & 41 & 41 & 18 \\
\hline
\end{tabular}

Source: personal findings.

d) younger scholars were more eager to recognise the autonomisation of the Studies of Tourism than their older colleagues (Table 9).

Table 9

Studies of Tourism as an autonomous scientific discipline by age of researcher in Polish subsample (in \%)

\begin{tabular}{|l|c|c|c|}
\hline \multicolumn{1}{|c|}{ Age of researchers } & Yes & No & Uncertain \\
\hline$\leq 35$ years of age & 50 & 20 & 30 \\
\hline ages $36-50$ & 44 & 36 & 20 \\
\hline ages $>50$ & 50 & 33 & 17 \\
\hline
\end{tabular}

Source: personal findings.

The results of the survey in the Polish subsample allow a formulation of more general conclusions:

1. A significant majority of the respondents $(63 \%)$ claim that they conduct their research projects on tourism within various paradigms of the "traditional" scientific disciplines. Only $24 \%$ express the opinion that they base on the specific paradigms which belong to the studies of tourism.

2. At the same time, a slight majority of the respondents (50\%) consider themselves representatives of the traditional scientific disciplines, however as much as $41 \%$ of the respondents are ready to call themselves representatives of the Studies of Tourism. It is worth noticing that the percentage of those ready to call themselves representatives of the Studies of Tourism is much 
higher than the percentage of those who are ready to acknowledge the existence of the specific paradigms of the studies of tourism.

3. Finally, almost half of the respondents (49\%) are ready to formally recognise the Studies of Tourism as an autonomous scientific discipline (Tourism does not have that status in the Polish system of sciences); $32 \%$ hold the opposing view.

4. The analysis reveals a strange inconsistency in the responses of the informants regarding the scientific (and methodological) identity and the formal status of the Studies of Tourism. On the one hand, they quite clearly advocate the autonomy of the Studies of Tourism, on the other hand, they seem to be attached to the paradigms of other disciplines of which they themselves feel representatives (Figure 1).

During my research of tourism I base on the specific tourism studies paradigms

During my research of tourism I feel a representative of the Studies of Tourism

Yes for the Studies of Tourism as an autonomus discipline

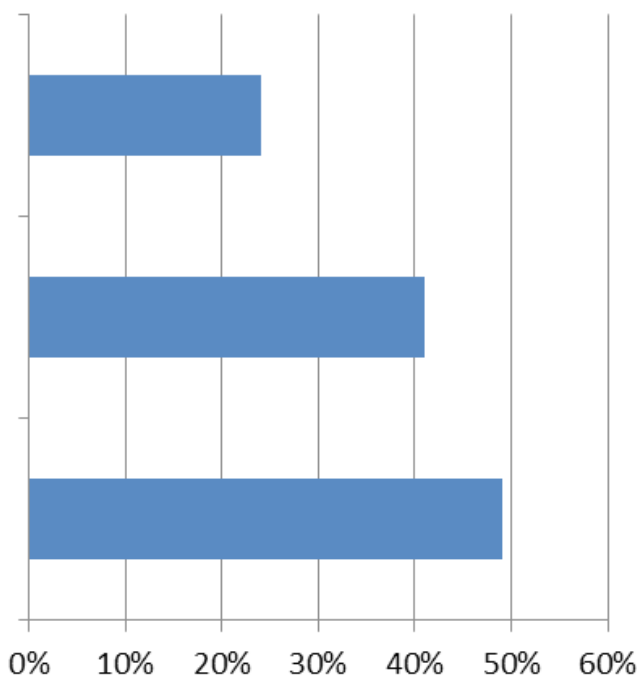

Fig. 1. The scientific identity of tourism research according to Polish respondents Source: personal findings.

\section{Analysis - international subsample}

1. Scientific paradigms in the studies of tourism:

a) the majority of respondents (50\%) claim that they conduct their research projects within the paradigms of traditional scientific disciplines; $45 \%$ of the re- 
spondents, however, state that they use the specific paradigms of the studies of tourism - Figure 2, (5\% has not expressed an opinion on this matter);

b) the bigger the theoretical output of a given discipline, the bigger the scholars' attachment to its paradigms (Economics $-55 \%$, Geography $-49 \%$, Physical Culture \& Sport - 39\%) - Table 10;

Table 10

Scientific paradigms in the studies of tourism by disciplines according to international scholars (in \%)

\begin{tabular}{|l|c|c|c|}
\hline \multicolumn{1}{|c|}{ Disciplines } & $\begin{array}{c}\text { Traditional } \\
\text { Paradigms }\end{array}$ & $\begin{array}{c}\text { Specific tourism } \\
\text { studies paradigms }\end{array}$ & Uncertain \\
\hline Economics & 55 & 42 & 3 \\
\hline Geography & 49 & 44 & 7 \\
\hline Physical Culture \& Sport & 39 & 44 & 17 \\
\hline Other disciplines & 51 & 47 & 2 \\
\hline
\end{tabular}

Source: personal findings.

c) the group of full professors (55\%) and Master's Degree holders (52\%) is relatively the most eager to recognise a new paradigm of the studies of tourism; on the other hand, the representatives of Ph.D. holders (63\%) and associate professors (47\%) claim that their research projects on tourism are conducted within the paradigms of the traditional disciplines (Table 11).

Table 11

Scientific paradigms in the studies of tourism

by scientific degrees in international subsample (in \%)

\begin{tabular}{|l|c|c|c|}
\hline \multicolumn{1}{|c|}{ Scientific degree } & $\begin{array}{c}\text { Traditional } \\
\text { Paradigms }\end{array}$ & $\begin{array}{c}\text { Specific tourism } \\
\text { studies paradigms }\end{array}$ & Uncertain \\
\hline Master's & 38 & 52 & 10 \\
\hline Ph.D. & 63 & 35 & 2 \\
\hline Associate Professor & 47 & 46 & 7 \\
\hline Full Professor & 39 & 55 & 6 \\
\hline
\end{tabular}

Source: personal findings.

2. Tourism scholars and their relationships with various scientific traditions:

a) a minority of the respondents claim that when doing research on tourism they feel they are representatives of their mother disciplines (33\%), while 
a significant majority (59\%) of the respondents state that they represent the Studies of Tourism (Figure 2); 8\% are "uncertain";

b) $75 \%$ of the respondents who represent the Physical Culture \& Sport sciences claim that they feel they are representatives of the Studies of Tourism; in other groups of disciplines respective indices are lower but all of them have exceeded the level of $50 \%$ (Table 12);

Table 12

International researchers of tourism as representatives of traditional disciplines or the Studies of Tourism by represented discipline (in \%)

\begin{tabular}{|l|c|c|c|}
\hline \multicolumn{1}{|c|}{ Scientific disciplines } & Traditional disciplines & Studies of Tourism & Uncertain \\
\hline Economics & 37 & 54 & 9 \\
\hline Geography & 37 & 61 & 2 \\
\hline Physical Culture \& Sport & 25 & 75 & 0 \\
\hline Other disciplines & 32 & 56 & 12 \\
\hline
\end{tabular}

Source: personal findings.

c) there are some significant differences between scholars (analysed by scientific grades) in terms of their attachment to their mother disciplines or to the new Studies of Tourism; respondents from the Full Professors group are the most eager (76\%) to call themselves representatives of the Studies of Tourism; on the other hand, Ph.D. holders are relatively more attached to their mother disciplines (Table 13);

Table 13

International researchers of tourism as representatives of traditional disciplines or the Studies of Tourism by scientific degrees (in \%)

\begin{tabular}{|l|c|c|c|}
\hline \multicolumn{1}{|c|}{ Scientific degree } & Traditional disciplines & Studies of Tourism & Uncertain \\
\hline Master's & 29 & 64 & 7 \\
\hline Ph.D. & 47 & 47 & 6 \\
\hline Associate Professor & 30 & 59 & 11 \\
\hline Full Professor & 15 & 76 & 9 \\
\hline
\end{tabular}

Source: personal findings.

3. The status of the Studies of Tourism as an autonomous scientific discipline: a) an apparent majority (53\%) of the respondents state that the Studies of Tourism deserve the status of an autonomous scientific discipline; 
$36 \%$ of the respondents hold the opposing view, while the remaining $11 \%$ does not have a clear opinion on this matter;

b) the holders of Full Professor's degree constitute the highest share (47\%) of the opponents of the autonomy of the Studies of Tourism; the proponents are mostly holders of the remaining degrees (Table 14);

Table 14

Studies of Tourism as an autonomous discipline

by scientific degrees in international subsample (in \%)

\begin{tabular}{|l|c|c|c|}
\hline \multicolumn{1}{|c|}{ Scientific degree } & Yes & No & Uncertain \\
\hline Master's & 60 & 33 & 7 \\
\hline Ph.D. & 49 & 33 & 18 \\
\hline Associate Professor & 62 & 31 & 7 \\
\hline Full Professor & 44 & 47 & 9 \\
\hline
\end{tabular}

Source: personal findings.

c) the percentage of those in favour of the Studies of Tourism as an autonomous discipline is similar in both groups (by years of experience in tourism research), although among scholars with longer experience as much as $41 \%$ are against it (Table 15 );

Table 15

Studies of Tourism as an autonomous discipline

by years of experience in researching tourism in international subsample (in \%)

\begin{tabular}{|l|c|c|c|}
\hline $\begin{array}{c}\text { Experience } \\
\text { in tourism research }\end{array}$ & Yes & No & Uncertain \\
\hline$\leq 10$ years & 54 & 29 & 17 \\
\hline$>10$ years & 52 & 41 & 7 \\
\hline
\end{tabular}

Source: personal findings.

d) the older and the youngest of the respondents are more eager to recognise the autonomisation of the Studies of Tourism than their middle-aged colleagues (Table 16). 
Studies of Tourism as an autonomous scientific discipline by the age of researcher in international subsample (in \%)

\begin{tabular}{|l|c|c|c|}
\hline Age of researcher & Yes & No & Uncertain \\
\hline$\leq 35$ years of age & 54 & 29 & 17 \\
\hline ages $36-50$ & 49 & 40 & 11 \\
\hline ages $>50$ & 58 & 34 & 8 \\
\hline
\end{tabular}

Source: personal findings.

The results of the survey in the international subsample allow a formulation of more general conclusions (Figure 2):

1. A slight majority of the respondents (50\%) claim that they conduct their research projects on tourism within various paradigms of the "traditional" scientific disciplines. At the same time as much as $45 \%$ express the opinion that they rely on the specific paradigms which belonged to the studies of tourism.

2. A significant majority of the respondents (59\%) consider themselves representatives of the Studies of Tourism, while 33\% of the respondents prefer to call themselves representatives of traditional disciplines. It is worth noticing that the percentage of those ready to call themselves representatives of the Studies of Tourism is bigger than the percentage of those who are ready to acknowledge the existence of specific paradigms of the studies of tourism.

3. Finally, an apparent majority of the respondents (53\%) is ready to formally recognise the Studies of Tourism as an autonomous scientific discipline (please note that in certain countries the Studies of Tourism have already enjoyed the status of an autonomous scientific discipline); $36 \%$ hold the opposing view.

4. The analysis suggests that international respondents as the whole seem to be rather consistent in their opinions about the scientific identity of tourism research - all the general indices are on a similar level. In particular cases, however, their opinions are quite surprising (e.g. the lack of consistency among Full Professors in their readiness to call themselves representatives of the Studies of Tourism and their apparent reserve in recognising the Studies of Tourism as an autonomous discipline). 


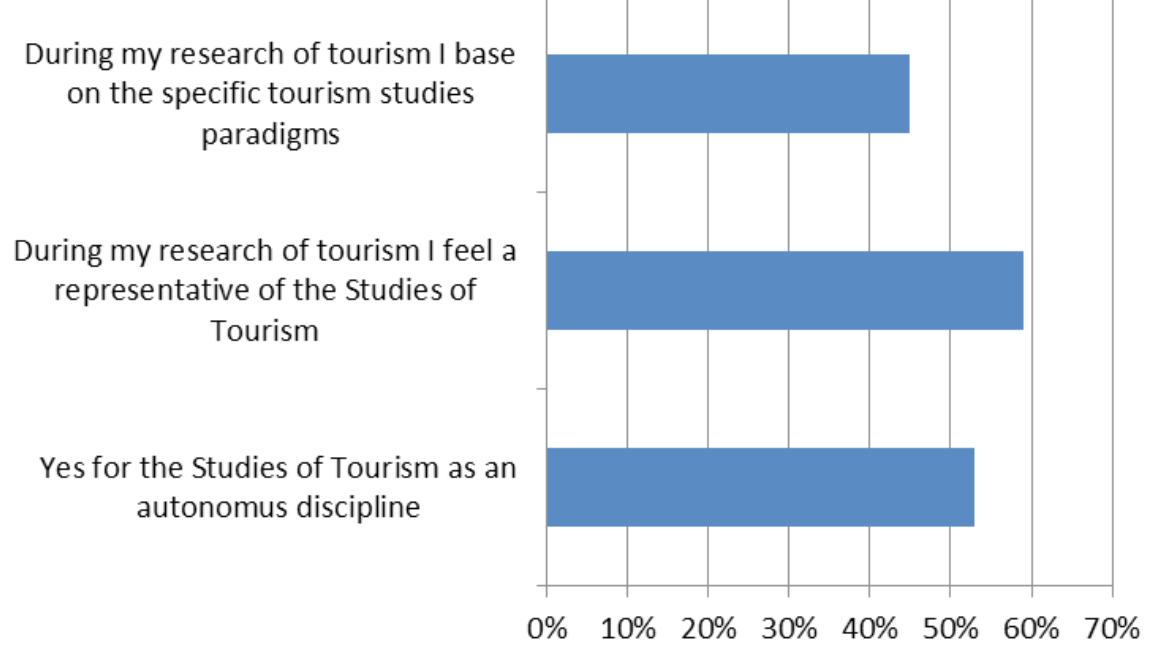

Fig. 2. The scientific identity of tourism research according to international respondents Source: personal findings.

\section{Conclusions - Polish versus international views on the scientific identity of tourism research}

As it was mentioned at the beginning of this paper, its aim is to find and reveal similarities and differences occurring among Polish and international scholars in terms of their views on the scientific identity of tourism research. The results of an appropriate comparative study is presented below..$^{98}$ They are divided into two groups: the differences and the similarities.

The differences in the opinions presented by Polish and international scholars on the scientific identity of tourism research can be identified on a general level, but they can also be broken down to particular aspects of the issue. Generally, the results of the survey suggest that international scholars are much more eager to recognise certain specificity of tourism research than their Polish colleagues. It is especially apparent in the comparison of the recognition of tour-

98 The study was of qualitative character and its results cannot be directly generalised. They include opinions presented by scholars who participated in the survey. 
ism studies paradigms and in the comparison of the identity of the scholars as representatives of traditional disciplines or the Studies of Tourism. It should be noted that the differences in these opinions are significant (Figure 3). On more detailed levels of analysis, many particular differences in the opinions expressed by Polish and international scholars have been identified. The most significant ones concern the following aspects: 1) only $24 \%$ of Polish respondents vs. $45 \%$ of the international respondents declare that they used specific paradigms of the studies of tourism; 2) $41 \%$ of Polish informants vs. 59\% of the international informants consider themselves representatives of the Studies of Tourism; 3) Polish researchers are much more consistent than their counterparts in their allegiance to traditional scientific paradigms (in the cross-section of all the academic degrees); 4) international scholars are much more eager to consider themselves representatives of the Studies of Tourism than their Polish colleagues (in all disciplines and degrees).

\section{- International scholars $\quad$ Polish scholars}

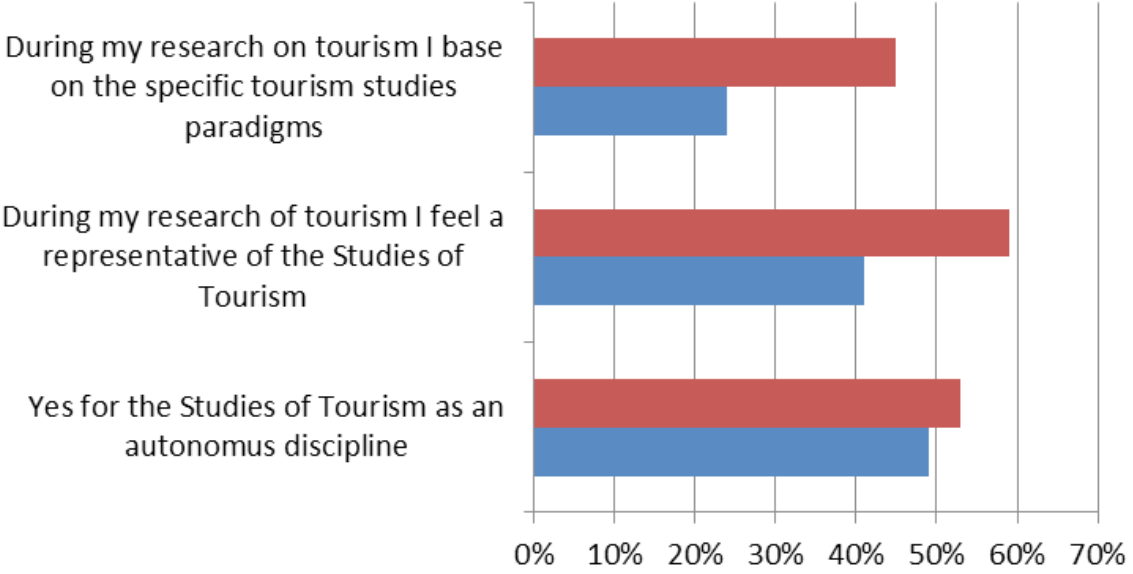

Fig. 3. Polish and international respondents' opinions on the scientific identity of tourism research

Source: personal findings.

On the other hand, there clearly are certain similarities in the views of Polish and international researchers. They are revealed in detailed analyses of the internal structure of particular responses and some dependencies occur- 
ring between them in certain categories. The most evident examples include the following cases: 1) the consistent opinions of Polish and international scholars suggesting that the bigger the theoretical output of a given discipline, the bigger the attachment of the scholars to its paradigms; 2) in both groups of respondents, Full Professors (among other degrees holders) are relatively the most eager to recognise a new paradigm of the studies of tourism and to call themselves representatives of the Studies of Tourism; 3) the structure of responses concerning the recognition of the autonomy of the Studies of Tourism by scientific degree is similar in the Polish and the international sample; 4) the same can be said about the responses giving grounds to the statements about the relationships occurring between the views on the autonomy of the Studies of Tourism, the age of researchers and the length of their experience in researching tourism. Apart from these findings, a more general conclusion seems worth stressing: in both subsamples similar groups of proponents and opponents of tourism as a separate discipline have been identified (Figure 4).

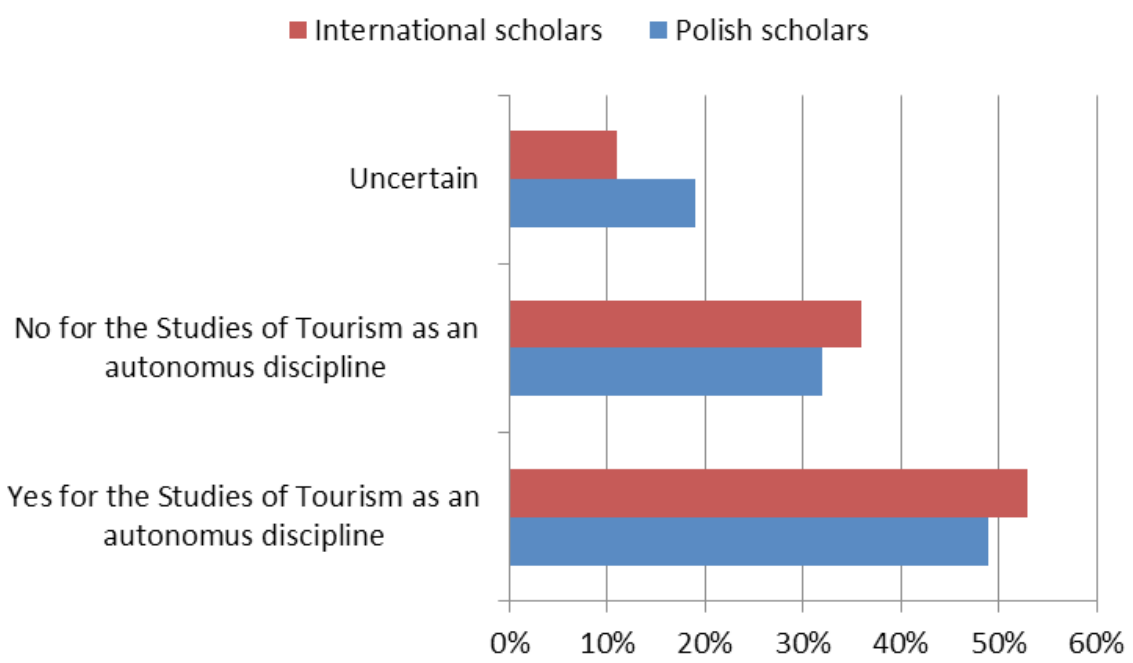

Fig. 4. Proponents and opponents of tourism as a separate disciplines among Polish and international scholars

Source: personal findings. 
Taking into account the above-mentioned findings and the conclusions from the survey carried out among the scholars of tourism of different schools and traditions, it is quite evident that Polish scholars of tourism hold a much more conservative position than their international colleagues as far as the recognition of the independent scientific identity of research of tourism is concerned. On the other hand, it should be noted that on a general level certain tendencies are shared by Polish and international scholars. These tendencies concern mainly the necessity of building certain methodological bases (understood as paradigms) on which research on tourism should be subsequently founded.

\section{Summary}

To sum up the particular observations and the results of the analysis, it could be stated that it is very difficult to precisely define the cognitive status of the contemporary studies of tourism. Undoubtedly, they are methodologically rooted in the "older" scientific disciplines which traditionally deal with the phenomena associated with tourism. Tourism scholars still use their methodological outputs. Unfortunately, the genuine output that could be credited to Tourism Sciences (understood as a separate discipline) seems to be still rather scarce. Also, academia (as suggested by the discussed results of the presented survey and the experience of the international debate from the 1990s-2000s) is divided and, so far, it has not been able to come up with a common, coherent answer to this question.

It is quite clear that the main part of the argumentation of the opponents of tourism's own research identity has been based on such methodological premises as the lack of a commonly accepted definition of tourism and tourism's own theories and methods. Such critics often refer to the classical Kuhn's model and the notions of scientific paradigm and normal science. There are, however, ways of arguing against this logic. As regards the classical methodological models of the development of sciences, it is worth mentioning that they are suited to the needs of natural sciences rather than social sciences and humanities. If academia was to rely only on these models, other social sciences could have the same problem with the recognition of their identity. And yet nowadays nobody seems to be questioning sociology, cultural anthropology, ethnography or ethnology as academic disciplines (although, in the past, all of them were criticized from the methodological positions of natural 
sciences). Moreover, in a wider methodological context, it seems that an attempt to impose on tourism studies so rigid a framework that was built for different purposes is a rather positivist postulate. Paradoxically, the most prominent opponent of such an approach was Kuhn himself (Okasha $\left.{ }^{99}\right)$, who questioned the dominant role of logical positivists and Popper's vision of science. He criticized them for focusing only on the "context of justification" and not paying enough attention to social, historical and cultural circumstances in the process of development of a science ("context of discovery"). In the light of Kuhn and his followers (in particular the representatives of the "strong programme" in non-classical sociology of science) ideas concerning the significance of social environment for the development of a science (Barnes, ${ }^{100}$ Barnes \& Bloor ${ }^{101}$ ), a turn towards Leiper's argumentation in favour of tourism's own scientific identity seems justified. This author, strongly advocating the establishment of tourism's scientific identity, bases his opinion on the common social recognition of tourism as a field of activity and study. Additionally, from the practical point of view, academic legitimacy and scientific recognition of tourism could facilitate the funding of its research (Rátz, ${ }^{102} \mathrm{Hall}{ }^{103}$ ). The results of the survey and the justifications provided by the respondents in their comments suggest that many members of the academic community share this view.

Some time and space should also be devoted to the discussion of this "ominous" disciplinary tyrannical force which is employed as an argument against the establishment of tourism as a discipline. At first glance it seems convincing, but a closer investigation reveals various doubtful aspects. It may be useful to refer to the example of other social sciences whose object of research is extremely inter-disciplinary and difficult to define. In this regard they are similar to tourism studies and share with them the same methodological weaknesses. Yet, disciplines such as sociology, cultural anthropology, ethnology, ethnography and gender studies have successfully developed their academic identity. Representatives of these disciplines (in majority) were not afraid of this "mythical tyrannical

99 S. Okasha, Philosophy of Science. A Very Short Introduction, Oxford University Press 2002.

${ }^{100}$ B. Barnes, Scientific knowledge and sociological theory, Routledge, Oxon-New York 2009.

${ }^{101}$ B. Barnes, D. Bloor, Mocny program socjologii wiedzy, Wydawnictwo IFiS PAN, Warszawa 1993.

102 T. Rátz, Crossdisciplinarity...

${ }^{103}$ M. Hall, Reflexity and Tourism Research, in: Qualitative Research in Tourism, eds. J. Phillimore, L. Goodson, Routledge, London 2004, p. 147. 
force" that could limit their freedom as researchers. On the contrary, they felt that the emergence of the new disciplines could facilitate their efforts to win an academic recognition in the community of researchers.

Of course, this argumentation does not intend to discredit the inter- and crossdisciplinary approaches in the studies of tourism. They are, and certainly will be, necessary to cope with vast problems that involve tourism issues. On the other hand, it seems rather unquestionable that in order to develop a "post-modern" approach in tourism studies, it is necessary to first build ontological and epistemological foundations that would assure the methodological rigour of tourism research $\left(\right.$ Rát $\left.{ }^{104}\right)$. In this context, the form of the disciplinarity framework seems a reasonable proposal. Only then will it be possible to apply the next post-disciplinary stage safely. Otherwise we may end up in "methodological quicksands" and such a situation would surely encourage both the domination of other disciplines over tourism and the epistemological eclecticism of tourism studies.

The above deliberation offers a handful of arguments against the views of the opponents of tourism's own academic identity (especially understood as a separate discipline). This does not mean, however, that the supporters are absolutely right. It may be useful to analyse the problem from a wider cognitive perspective. In this context, the question whether we will be able to learn more about tourism using only its scientific identity or should we rather base on the outputs of other tourism-related sciences seems to be most reasonable; in other words - will we, by means of the academic identity of tourism, gain better knowledge of tourism. Taking into account so vast field of interest of tourism researchers (even after narrowing it down to Babu's "Tourism Development Studies" only), the answer still remains unclear. In this context, Hoerner's tourismologie and Jovicic's tourismology, as multidisciplinary and synthetic tourism sciences, do not appear to be achievable solutions due to their excessive field of study.

Perhaps a more feasible proposal for the tourism academic identity should focus on the search for certain specific - and at the same time constitutive features that would distinguish tourism research from other academic activities - disciplines, as they would point to the aspects that could not be managed in sat-

${ }^{104}$ T. Rátz, Crossdisciplinarity... 
isfactory ways by other sciences (Chojnicki, ${ }^{105}$ Maciołek $^{106}$ ). This would result in the researchers working (at least at the beginning) within a relatively narrow field centred around tourism-specific features. To sum up the whole discussion, it can be said that, from the cognitive perspective, the optimal position would be the one in which research is conducted using various disciplinary approaches and at the same time it focused on tourism-specific aspects. Finally, let us refer to a significant article by Tribe ${ }^{107}$ concerning the truth in tourism. The author presents quite a pessimistic view that it is probably impossible to find one truth about tourism. He formulates such an opinion on the basis of social constructionism which sees the world in relative terms. Such a perspective may result from observing various tourism phenomena through the lens of different disciplines. Indeed, it seems that such an attitude can lead at the most to different truths about tourism, as mentioned by Tribe. Perhaps an alternative approach, based on specificity and "constitutivitity" of certain aspects of tourism could bring us closer to a more "objective" truth about tourism, i.e. investigated from more critical-realistic positions as discussed by Botterill, Pointing, Hayes-Jonkers, Rodrigues, Jones \& Clough, ${ }^{108}$ Botterill ${ }^{109}$ and Pernecky. ${ }^{110}$

\section{References}

Airey D., Tourism Education Life Begins at 40., "Téoros" 2008, No. 27 (1).

Aronowitz S., Giroux H., Postmodern education: politics, culture and social criticism., University of Minnesota Press, Minneapolis 1991.

Ateljevic I., Pritchard A., Morgan N., The critical turn in tourism studies: innovative research methodologies, Elsevier, Amsterdam, Netherlands 2007.

${ }^{105}$ Z. Chojnicki, Charakter i sytuacja nauki o turystyce-rozważania metodologiczne, Zeszyty Naukowe Wyższej Szkoły Gospodarki Bydgoszcz, Turystyka i Rekreacja 3, Bydgoszcz 2005, pp. 11-23.

${ }^{106}$ R. Maciołek, Osobliwości metodologiczne badań nad turystyka, Zeszyty Naukowe Wyższej Szkoły Turystyki i Hotelarstwa w Bydgoszczy 2, Bydgoszcz 2002, pp. 17-26.

${ }^{107}$ J. Tribe, Tribes...

${ }^{108}$ D. Botterill, S. Pointing, C. Hayes-Jonkers, C. Rodrigues, T. Jones, A. Clough, Violence, tourism, security and critical realism, "Annals of Tourism Research" 2013, No. 42, pp. 311-333.

${ }^{109}$ D. Botteril, Constructionism - A critical realistic reply, "Annals of Tourism Research" 2014, No. 48, pp. 292-298.

${ }^{110}$ T. Pernacky, Constructionism, critical pointers for tourism studies, "Annals of Tourism Research" 2012, No. 39 (2), pp. 1116-137; T. Pernacky, Realist and constructionist shades of grey, “Annals of Tourism Research" 2014, No. 48, pp. 295-298. 
Athiyaman A., Knowledge development in tourism: Tourism demand research, "Tourism Management" 1997, No. 18 (4).

Babu S.S., Tourism as Disciplines and Industry. Some comments on the progressing debates, in: Tourism Development Revisited. Concepts, Issues and Paradigms, eds. S.S. Babu, S. Mishra, B.B. Parida, SAGE, 2008.

Barnes B., Scientific knowledge and sociological theory, Routledge, Oxon-New York 2009.

Barnes B., Bloor D., Mocny program socjologii wiedzy, Wydawnictwo IFiS PAN, Warszawa 1993.

Barnett R., The idea of higher education, "Buckingham: The Society for Research into Higher Education", Open University Press, 1990.

Barnett R., Higher education, a critical business, "Buckingham: The Society for Research into Higher Education", Open University Press, 1997.

Bernstein R. Beyond Objectivism and Relativism: Science, Hermeneutics and Praxis, University of Pennsylvania, Philadelphia 1991.

Borret A., Discipline d'enseignement, sujet d'études, "Revue Espaces" 2005, No. 223.

Botteril D., Constructionism - A critical realistic reply, "Annals of Tourism Research" 2014, No. 48.

Botterill D., Pointing S., Hayes-Jonkers C., Rodrigues C., Jones T., Clough A., Violence, tourism, security and critical realism, "Annals of Tourism Research" 2013, No. 42.

Bowedes T., Development of advanced tourism studies in Holland, "Annals of Tourism Resarch"1982, No. 9.

Butowski L., Tourism - an academic discipline, "Turyzm” 2011, No. 21/1-2.

Butowski L., Tourism Policy - Definitions, Origin and Evolution, "Problems of Tourism and Recreation" 2012, No. 1.

Butowski L. The phenomenology of tourism: in search of the essence of the phenomenon. Towards new paradigms for tourism research, in: Tourism Research in a Changing World, eds. F. Dias, J. Kosmaczewska, E. Dziedzic, A. Mogliulo, GITUR - Tourism Research Group of Polytechnic Institute of Leiria, 2014.

Butowski L. The ontological and epistemological foundations of tourism research. Scientific identity of Polish scholars of tourism, "Economic Problems of Tourism" 2014, No. 4 (28).

Butowski L. (ed.), Searching for the scientific identity of tourism research, Warsaw School of Tourism and Hospitality Management, Warszawa 2014.

Cazes G., À propos de tourismologie. La science par autoproclamation, "Revue Espaces" 2001, No. 187.

Ceriani-Sebregondi G., Chapuis A., Gay J-C., Knafou R., Stock M., Violier P., Quelle serait l'objet d'une " science du tourisme » ?, "Téoros" 2008, No. 27 (1).

Chłopecki J., Turystologia jako dyscyplina naukowa, in: Turystyka w badaniach naukowych, eds. R. Winiarski, W. Alejziak, AWF, WSIiZ, Kraków-Rzeszów 2005.

Chojnicki Z., Charakter i sytuacja nauki o turystyce - rozważania metodologiczne, Zeszyty Naukowe Wyższej Szkoły Gospodarki Bydgoszcz, „Turystyka i Rekreacja” No. 3, Bydgoszcz 2005. 
Cohen E., Rethinking the sociology of tourism, "Annals of Tourism Research" JanuaryMarch 1979.

Coles T., Hall M., Duvall D., Mobilising tourism: A Post Disciplinary Critique, "Tourism Recreation Research" 2005, No. 30 (2).

Comic D., Tourism as a Subject of Philosophical Reflection, "Revue de Tourisme" 1989, No. 44.

Cuffy V., Tribe J., Airey D., Lifelong Learning for Tourism, "Annals of Tourism Research" 2012, No. 39 (3).

Dann G., Nash D., Pearce P., Methodology in Tourism Research, "Annals of Tourism Research" 1988, No. 18.

Darbellay F., Stock M., Tourism as complex interdisciplinary research object, "Annals of Tourism Research" 2012, No. 39 (1).

Devailly J-M., Géographie du tourisme. Pérégrinité ou chaos?, L'Harmattan, Paris 2006.

Dewailly J.-M., Complexité touristique et approche transdisciplinaire du tourisme, "Téoros" 2008, No. 27 (1).

Echtner C.M, Jamal T.B., The Disciplinary Dilemma of Tourism Studies, "Annals of Tourism Research" 1997, No. 24.

Franklin A., Crang M., The Trouble with Tourism and Travel Industry, "Tourist Studies" 2001, No. 1 (1), 22.

Goeldner C.R., The evaluation of tourism as an industry and a discipline, Paper presented at the International Conference for Tourism Educators, University of Surrey, Guildford 1988.

Goeldner C.R., Ritchie J.R.B., Tourism: Principles, Practices, Philosophes, John Wiley \& Sons, Hoboken (N.J.) 2006.

Hall M., Reflexity and Tourism Research, in: Qualitative Research in Tourism, eds. J. Phillimore, L. Goodson, Routledge, London 2004.

Hall M., Williams A., Lew A., Tourism: Conceptualisations, Institutions and Issues, in: A Companion to Tourism, eds. A. Lew, M. Hall A. Williams, Blackwell, Oxford 2004.

Hillali M., La science du tourisme dans le discours des acteurs internationaux; débat ou polémique?, "Téoros" 2008, No. 27 (1).

Hoerner J-M., Pour la reconnaissance d'une science touristique, "Revue Espaces" 2000, No. 173.

Hoerner J-M., Pour une novelle définition du tourisme, "Revue Espaces" 2002, No. 224.

Hoerner J-M., Contrubution à la science du tourisme, "Téoros" 2008, No. 27 (1), http:// teoros.revues.org/355.

Hoerner J-M., Sicart C., La science du tourisme, Balzac Editeur, 2003.

Hunziker W., Krapf, K., Grundriss der allgemeinen Fremdenverkehrslehre, Polygraphischer Verlag, Zurich 1942.

Jafari J., Research and scholarship: The basis of toursm education, "Journal of Tourism Studies" 1990, No. 1.

Jafari J., The Scientification of Tourism, in: Hosts and Guests Revisited: Tourism Issues in the 21st Century, eds. V.L. Smith, M.A. Brent, Cognizant Communication Corporation, New York 2001. 
Jovicic Z., A Plea for Tourismological Theory and Methodology, "Revue de Tourisme" 1988, No. 43.

Kadri B., La question du statut scientifique du tourisme: presentation, http://teoros. revues.org/345.

Knafou R., La recherche en tourisme s'organise, „Revue Espaces“ 2005, No. 225.

Kuhn T.S., The Structure of Scientific Revolutions, 3rd ed., University of Chicago, 1996.

Leiper N., Towards a cohesive curriculum tourism: The case for a distinct discipline, "Annals of Tourism Research" 1981, No. 8 (1).

Leiper N., Tourism Systems: An Interdisciplinary Study, “Occasion Papers” 2, Massey University 1990.

Leiper N., An Emerging Discipline, “Annals of Tourism Research” 2000, No. 27.

Liszewski S., Nauka czy nauki o turystyce, „Turyzm” 2010, No. 20 (2).

Lynch P., Brown R., Utility of Large-scale Leisure Research Agendas, "Managing Leisure" 1999, No. 7 (4).

Maciołek R., Osobliwości metodologiczne badań nad turystyka, Zeszyty Naukowe Wyższej Szkoły Turystyki i Hotelarstwa w Bydgoszczy No. 2, Bydgoszcz 2002.

Mazurkiewicz L., Czy istnieje teoria turystyki?, „Problemy Turystyki” 2005, No. 3/4.

Mazurkiewicz L., Wybrane teorie oraz metody badawcze turystyki, Studia i Monografie AWF, Warszawa 2012.

McKercher B., Prideaux B., Academic myths of tourism, "Annals of Tourism Research" 2014, No. 46.

Meethan K., Tourism in Global Society: Place, Culture and Consumption, Palgrave, New York 2001.

Okasha S., Philosophy of Science. A Very Short Introduction, Oxford University Press, 2002.

Page S.J., Evaluating Research Performance in Tourism: The UK Experience, "Tourism Management" 2003, No. 24 (4).

Pearce P.L., Defining Tourism Study as a Specialism: A Justification and Implications, "Téoros International" 1993, No. 1.

Pearce P.L., Butler R., Tourism Research: Critiques and Challenges, Routledge, London 1993.

Pernacky T., Constructionism, critical pointers for tourism studies, "Annals of Tourism Research" 2012, No. 39 (2).

Pernacky T., Realist and constructionist shades of grey, "Annals of Tourism Research" 2014, No. 48.

Rátz T., Crossdisciplinarity or tourismology? The scientific identity of tourism in Hungary, in: Searching for the scientific identity of tourism research, ed. L. Butowski, Warsaw School of Tourism and Hospitality Management, Warszawa 2014.

Rátz T., Kátay Á., Skills and Competencies in Tourism Employment - A Cultural Analysis of Expectations and Experiences, in: (Inter)cultural Aspects of Tourism Development, eds. T. Rátz, Cs. Sárdi, Kodolányi János University College, Székesfehérvár 2007. 
Ritchie J.R.B, Sheehan L.R., Timur, S., Tourism Sciences or Tourism Studies? Implications for the Design and Content of Tourism Programming, "Téoros. Revue de Recherche en Tourisme" 2008, No. 27-1.

Rogoziński K., Tourism as a Subject of Research and Intergration of of Sciences, "Problemy Turystyki" 1985, No. 4.

Rojek C., Urry J., Touring cultures, Routledge, London 1997.

Ryan C., Tourism a Mature Subject Discipline?, "Pacific Tourism Review” 1997, No. 1 (1).

Ryan C., Academia- industry tourism research links: states of confusion, "Pacific Tourism Review" 2001, No. 5 (3/4).

Shariff N.M., Reforming Hospitality Program of Higher Educational Institutions, "Anatolia - An International Journal of Tourism and Hospitality Research" 2011, No. 22 (1).

Stafford J., Le paradigm culturaliste en téorologie: étude, analyse et critique, "Téoros" 1985, No. 7 (1).

Stafford J., Connaissances en tourisme et reconnaissance sociale, "Téoros" 1992, No. 11 (1).

Stradner J., Der Fremdenverkehr, Leykam, Graz 1905.

Szubert-Zarzeczny U., Kilka uwag o potrzebie autonomizacji „nauki o turystyce”, Zeszyty Naukowe AWF w Krakowie No. 81, Kraków 2001.

Taillon J., Understanding tourism as an academic community, study, or discipline, „Journal of Tourism \& Hospitality“ 2014, No. 3 (3).

Tooman H., Müristaja H., Holleran J.N., Developing a Curriculum for the Needs of the Tourism Sector in a Transition Country, the Example of Pärnu College of the University of Tartu, Paper presented at the 25th EuroChrie Conference, Leeds, 25-27 October 2007.

Tribe J., The Indiscipline of Tourism, "Annals of Tourism Research" 1997, No. 24.

Tribe J., The RAE-ification of tourism research in the UK, "International Journal of Tourism Research" 2003, No. 5.

Tribe J., The truth about tourism, "Annals of Tourism Research" 2006, No. 33 (2).

Tribe J. Tribes, territories and networks in the tourism community, "Annals of Tourism Research" 2010, No. 37 (1).

Vicériat P., Origet du Cluzeau C., Balfet M., Ensemble pour la reconnaissance d'une science du tourisme, "Revue Espaces" 2005, No. 224.

Weiler B., Tourism Research and Theories: A Review, in: Tourism and Hospitality Industry in the 21st Century, eds. A. Lockhood, S. Medlik, ButterworthHeinemann, London 2003.

Witt S., Broke M., Buckley P., The management of International Tourism, Unwin Hyman, London 1991.

Wyrzykowski J., Achievements of geographical sciences in Poland in tourism research, in: Searching for the scientific identity of tourism research, ed. L. Butowski, Warsaw School of Tourism and Hospitality Management, Warszawa 2014. 


\section{TOŻSAMOŚĆ NAUKOWA W BADANIACH NAD TURYSTYKĄ W OPINIACH POLSKICH I ZAGRANICZNYCH BADACZY}

\section{Streszczenie}

Celem artykułu jest przedstawienie wyników badań empirycznych poświęconych tożsamości naukowej polskich i zagranicznych badaczy turystyki. Zostały one zaprezentowane w świetle dorobku angielsko i francuskojęzycznej literatury oraz polskich prac, które ukazały się w ciągu ostatnich kilku dziesięcioleci. Artykuł składa się z trzech zasadniczych części, które zawierają: 1) dyskusję teoretyczną i przegląd wyników wcześniejszych badań dostępnych w wybranych źródłach; 2) prezentację wyników badań empirycznych nad tożsamością naukową polskich i zagranicznych badaczy turystyki; 3) wnioski końcowe o charakterze teoretyczno-metodologicznym dotyczące sytuacji poznawczej i formalnego status badań nad turystyką.

Badania empiryczne, których wyniki przedstawiono w niniejszym artykule mają charakter jakościowy (nie spełniały kryterium reprezentatywności) i zostały przeprowadzone na celowej próbie polskich i zagranicznych badaczy turystyki w 2013 i 2014 roku. Próba zagraniczna liczyła 180 naukowców o zróżnicowanym doświadczeniu, wieku i dorobku naukowym (od stopnia magistra do profesora). Reprezentowali oni publiczne i prywatne uniwersytety, ośrodki badawcze oraz stowarzyszenia zrzeszające badaczy turystyki z blisko 50 krajów, ze wszystkich kontynentów. Grupa polska liczyła 90 badaczy - przedstawicieli różnych dyscyplin naukowych zajmujących się turystyką. Reprezentowali oni najważniejsze krajowe centra akademickie i naukowe prowadzące studia nad tą dziedziną.

Wyniki tych badań pokazują dość jednoznacznie, że Polscy badacze prezentują dużo bardziej zachowawcze stanowisko dotyczące uznania tożsamości naukowej badań nad turystyką (przejawiającej się w uznaniu specyficznych paradygmatów naukowych, poczuciu przynależności do wspólnoty badaczy turystyki oraz w akceptacji nowej dyscypliny naukowej). Jednocześnie zauważono także sporo podobieństw odnoszących się do poszczególnych zagadnień związanych z przedmiotem badań. Z drugiej strony należy podkreślić, że zarówno wśród polskich, jak i zagranicznych naukowców uwidoczniły się znaczne wewnętrzne różnice poglądów na temat tożsamości naukowej badań nad turystyką, zwłaszcza w zakresie ich statusu poznawczego oraz formalnego.

Niniejszy artykuł zawiera rozwinięcie dyskusji prowadzonej we wcześniejszych tekstach autora opartych głównie na badaniach nad tożsamością naukową polskich badaczy turystyki.

Słowa kluczowe: tożsamość naukowa w badaniach nad turystyką, poglądy polskich i zagranicznych badaczy turystyki 